\title{
Transplantacija bubrega u starijih
}

\section{Kidney transplantation in the elderly}

\author{
Lidija Orlić, Ita Jelić Pranjić
}

Zavod za nefrologiju, dijalizu i transplantaciju bubrega, Klinika za internu medicinu, KBC Rijeka, Rijeka, Hrvatska

\section{"Dopisni autor:}

Prof. dr. sc. Lidija Orlić, dr. med.

Tome Strižića 3, 51000 Rijeka

E-mail: lidija.orlic@gmail.com
Sažetak. Broj starijeg stanovništva u stalnom je porastu, kao i udio starijih pacijenata s kroničnom bubrežnom bolesti. Općepoznato je da je transplantacija bubrega najbolja metoda nadomjesnog bubrežnog liječenja, ima najbolje rezultate preživljavanja i značajno utječe na poboljšanje kvalitete života. Transplantacija bubrega u starijih također je pokazala bolje preživljavanje. Zbog pratećih bolesti u ovoj skupini pacijenata potrebna je detaljna prijetransplantacijska obrada, posebno na kradiovaskularne i maligne bolesti. Starenjem se javljaju promjene u imunitetu, farmakokinetici i farmakodinamici lijekova, koje treba poznavati da bi se sastavio optimalni imunosupresivni protokol. U Kliničkom bolničkom centru Rijeka postoje dugogodišnja iskustva s transplantacijom bubrega u starijih primatelja.

Ključne riječi: imunosupresivna terapija; preživljavanje; stariji pacijenti; transplantacija bubrega

Abstract. The elderly population is steadily increasing, as is the proportion of elderly patients with chronic kidney disease. It is known that kidney transplantation is the best method of renal replacement therapy, has the best survival results and has a significant effect on improving the quality of life. Renal transplantation in the elderly has also shown better survival rate. In this group of patients, through pretransplant evaluation is needed due to accompanying comorbidities, especially for cardiovascular and malignant diseases. Changes in immunity, pharmacokinetics and pharmacodynamics of drugs occur with aging and need to be known in order to determine an optimal immunosuppressive protocol. Clinical Hospital Center Rijeka has many years of experience with kidney transplantation in elderly recipients.

Key words: elderly patients; immunosuppressive therapy; kidney transplantation; survival 


\section{UVOD}

Zahvaljujući napretku u medicini i promjeni životnog stila, u proteklom stoljeću je došlo do značajnog produženja ljudskog životnog vijeka. Krajem devetnaestog stoljeća očekivano trajanje života bilo je tek nešto više od 30 godina. Sada u razvijenim zemljama ono iznosi više od 70 godina, a pretpostavlja se da će uskoro iznositi i preko 80 godina'. Stanovništvo starije od 65 godina danas čini značajni udio u općoj populaciji, u razvijenim zemljama oni čine udio i više od $20 \%$. U Republici Hrvatskoj, prema posljednjem popisu stanovništva iz 2011. godine, starijih od 65 godina bilo je 17,3 \% (muškaraca $14 \%$, žena 20,4 \%) ${ }^{2}$. Incidencija kronične bubrežne bolesti (KBB) također je u stalnom porastu ${ }^{3}$. Nekada, ne tako davno, stariji pacijenti nisu se uključivali na nadomjesno bubrežno liječenje, kako dijalizu tako i transplantaciju. Napretkom u medicini i boljim mogućnostima liječenja starijim pacijentima, jednako kao i mlađima, danas su dostupne sve metode nadomjesnog bubrežnog liječenja, uključujući i transplantaciju bubrega. Prema različitim registrima za nadomjesno liječenje oni čine velik udio u ukupnom broju pacijenata. Medijan dobi za pacijente koji počinju nadomjesno liječenje u Hrvatskoj prema zadnjim podacima iz 2014. godine bio je 67 godina (muškarci 66, žene 70 godina) ${ }^{4}$. Stariji od 65 godina čine više od polovicu pacijenata koji su započeli nadomjesno liječenje dijalizom ${ }^{5}$. Zbog toga je broj starijih pacijenata na listama za transplantaciju bubrega u porastu, a sve većem broju starijih pacijenata uspješno se vrši transplantacija ${ }^{6}$.

\section{UČESTALOST I ISHODI TRANSPLANTACIJE} BUBREGA U STARIJIH PACIJENATA

Prema podacima iz registra Sjedinjenih Američkih Država (SAD) bilježi se značajan porast starijih primatelja bubrežnog transplantata u posljednjim dekadama, od 4,2 \% do $17,2 \%$ u 2012. godini, te se taj trend porasta nastavlja i dalje. Također od ukupnog broja transplantiranih pacijenata prema registru te iste godine, $23,3 \%$ bili su stariji od 65 godina. Skandinavske zemlje također bilježe sve veći broj pacijenata starijih od 65 godina na nadomjesnom liječenju, kao i starijih transplantiranih pacijenata ${ }^{7,8}$.
Većina studija pokazala je bolje preživljavanje starijih pacijenata nakon transplantacije u odnosu na pacijente koji su na dijalizi i na listi čekanja. Čak i u pacijenata starijih od 70, pa i 80 godina, transplantacijom se postiže bolje preživljavanje ${ }^{9-11}$. Posebne skupine starijih pacijenata, kao dijabetičari i pacijenti s hipertenzivnom bolesti bubrega, također nakon transplantacije imaju bolje preživljavanje u odnosu na dijalizu ${ }^{12-14}$. Osim boljeg preživljavanja postiže se bolja kvaliteta života, a financijski je transplantacija i u ovoj sku-

Većina studija pokazala je bolje preživljavanje starijih pacijenata nakon transplantacije $u$ odnosu na pacijente koji su na dijalizi i na listi čekanja, čak i u pacijenata starijih od 70, pa i 80 godina. Posebne skupine starijih pacijenata, kao dijabetičari, i pacijenata s hipertenzivnom bolesti bubrega također imaju bolje preživljavanje nakon transplantacije.

pni pacijenata isplativija u odnosu na kroničnu hemodijalizu ${ }^{15-17}$. Nažalost, u velikom broju radova kao dobna granica za stariju životnu dob uzeta je dob od 60 godina, što utječe na dobivene rezultate i onemogućava usporedbu i njihovo tumačenje.

Studija škotskih autora iz 2013. godine, koja je obuhvatila desetogodišnje razdoblje, pokazala je kako stariji primatelji koji su dobili bubreg od starijih darivatelja imaju značajno viši postotak odgođene funkcije transplantata u odnosu na mlađe (40,7 \% prema 16,9\%). Nije bilo razlike u jednogodišnjem preživljavanju spram mlađih primaoca, kao ni u gubitku transplantata. Stariji primatelji imali su manje akutnog odbacivanja (6,8 \% spram $22 \%)$, ali su značajno imali više hospitalizacija ${ }^{18}$.

$\mathrm{U}$ ispitivanju korejskih autora udio transplantacija u primatelja starijih od 60 godina bio je 6,7 \%; njihovo jednogodišnje preživljavanje bilo je 93,3\%, a petogodišnje $91,3 \%$. Glavni uzrok smrti su bile infekcije ${ }^{19}$.

Prema podacima japanskih autora nije bilo razlike u preživljavanju između mlađih i starijih primatelja, a glavni uzrok smrti u starijih primatelja bilo je srčano popuštanje ${ }^{20}$.

Rad talijanskih autora iz Barija pokazao je lošije preživljavanje starijih primatelja u odnosu na 
mlađe, a vodeći uzrok smrti su bile kardiovaskularne bolesti i malignomi. Nije bilo razlike u učestalosti akutnog odbacivanja transplantata $u$ odnosu na mlađe ${ }^{21}$. Rad rimskih autora također je pokazao da starija životna dob nije bila povezana s negativnim ishodima nakon transplantacije bubrega, dok je viša stopa smrtnosti u ovoj skupini pacijenata bila povezana s pratećim bolestima, posebno s dijabetesom ${ }^{22}$.

\section{FAKTORI KOJI UTJEČU NA ISHOD TRANSPLANTACIJE U STARIJOJ ŽIVOTNOJ DOBI}

Sigurno je da stariji pacijenti s KBB-om imaju veći broj pratećih bolesti u odnosu na mlađe dobne skupine. To prvenstveno uključuje kardiovaskularne bolesti, maligne bolesti i infekcije (tablica 1). Prisutnost pratećih bolesti povećava rizik za mortalitet i morbiditet, što je još više izraženo kod starijih ${ }^{13,14}$.

Govoreći o starijim pacijentima često se koristi pojam fizičke slabosti, koji se prema gerontolozima definira kao: „Medicinsku sindrom s višestrukim uzrocima i doprinosima koji je karakteriziran smanjenom snagom, izdržljivošću i smanjenim fiziološkim funkcijama, koji povećava rizik za ovisnost ili smrt.“

U ovoj skupini pacijenata često su smanjene kognitivne funkcije, a pacijenti su često značajno ograničeni u svojim mogućnostima zbog slabosti $\mathrm{i}$ smanjene pokretljivosti² ${ }^{23}$. Uz to, vrijeme provedeno na dijalizi prije transplantacije, kao i vrijeme na listi čekanja, utječu na ishod transplantacije. $\mathrm{U}$ procjeni slabosti, smanjene pokretljivosti i kognitivnih sposobnosti u gerijatriji, često se koriste različiti indeksi kao Charlton Comorbidity Indeks, Lawtonova skala ili Monteral Cognitive Assessment. Oni mogu na neki način liječnika usmjeriti na moguće dodatne probleme koji mogu nastati nakon transplantacije, kao i pomoći u procjeni je li navedeni kandidat pogodan za transplantaciju. Stariji transplantirani pacijenti zbog pratećih bolesti, pored imunosupresivne terapije, uzimaju u većini slučajeva još dodatnu terapiju, što utječe na suradljivost.

\section{TRANSPLANTACIJA „STARIJIH BUBREGA} U STARIJE PRIMATELJE"

U cilju brže transplantacije starijih pacijenata s liste čekanja osmislio se takozvani program „starijih bubrega (darivatelja) za starije primatelje“, u velikom broju zemalja u kojem je razvijen transplantacijski program. Prema iskustvima i podacima iz raznih transplantacijskih centara program „stariji starijima“ u transplantaciji bubrega pokazao je duže trajanje hospitalizacija, povećanje cijene samog postupka, povećani rizik za odgođenu funkciju transplantata te povećani rizik za infekcije.

U ovoj skupini transplantiranih pacijenata smanjeno je preživljavanje transplantata, a ako se preživljavanje transplantira cenzurira sa smrti, onda je preživljavanje identično. Prema registrima različitih europskih zemalja i prema registru SAD-a smrt pacijenata s funkcionalnim transplantatom je glavni gubitak transplantata u ovoj gru$\mathrm{pi}^{7,8}$.

Takozvani "senior" program u sklopu Eurotransplanta počeo je 1999. godine i njime je osmišljeno da stariji primatelji od 65 godina dobiju također

Tablica 1. Faktori koji utječu na ishod transplantacije bubrega u starijih primatelja

\begin{tabular}{|l|l|}
\hline \multicolumn{2}{|c|}{ FAKTORI KOJI UTJEČU NA ISHOD TRANSPLANTACIJE BUBREGA U STARIJIH PRIMATELIJA } \\
\hline \multicolumn{1}{|c|}{ Faktori sa strane primatelja } & \multicolumn{1}{c|}{ Faktori sa strane darivatelja } \\
\hline - Dob & - Dob \\
- Prateće bolesti & - Prateće bolesti \\
- Vrijeme provedeno na dijalizi prije transplantacije & - Bubrežna funkcija \\
- Vrijeme provedeno na listi čekanja & - Broj dana boravka u JIL-u \\
- Optimalna raspodjela organa & - Srčani arest i reanimacije \\
- Pušenje & - Uzrok smrt \\
- Indeks tjelesne mase & - Infekcije \\
& - Vrijeme hladne ishemije \\
\hline
\end{tabular}


bubrežni transplantat stariji od 65 godina. Također je u sklopu toga programa predviđena lokalna alokacija organa kako bi se smanjilo vrijeme hladne ishemije i na taj način poboljšalo preživljavanje transplantata. Vrlo često u ovih transplantacija postoji slaba HLA podudarnost između primatelja i darivatelja, što sigurno pridonosi lošijem preživljavanju transplantata ${ }^{24}$.

Takva transplantacija zahtijeva pažljivi odabir imunosupresivnog protokola, kako indukcijske terapije, tako i terapije održavanja. Posebnih protokola za ovu skupinu pacijenata nema, a preporuke se zasnivaju na postojećim generalnim preporukama za imunosupresiju. Prema posljednjem izvješću Eurotransplanta za 2018. godinu, prosječan medijan darivatelja bubrega bio je 55 godina, a $38 \%$ darivatelja u Hrvatskoj je bilo starije od 65 godina ${ }^{25}$.

Zbog lošijih rezultata u ovoj skupini pacijenata neupitno se nameće pitanje je li takva transplantacija bolja opcija od dijalize ${ }^{14,17}$.

Postoji druga mogućnosti transplantacije bubrega po principu „stariji starijemu“, a to je transplantacija od starijih živih darivatelja. Za razliku od transplantacije od starijih umrlih darivatelja, ova skupina ima bolje preživljavanje kako transplantata tako i pacijenata ${ }^{26}$. Također, preemptivna transplantacija u starijih primatelja od starih darivatelja pokazala je pozitivan utjecaj na poboljšanje ishoda ${ }^{27}$.

\section{OSOBITOSTI OBRADE STARIJIH PACIJENATA}

\section{ZA STAVLJANJE NA LISTU ČEKANJA}

Obrada za transplantaciju pacijenata starije životne dobi sprovodi se kao i za ostale pacijente. Međutim, starija životna dob povezana je s većom učestalošću pratećih bolesti. Zbog toga je, pored standardne obrade, u ovoj skupini pacijenata potrebna detaljnija obrada i procjena kardiovaskularnog sustava koja uključuje: anamnezu, fizikalni nalaz, elektrokardiogram, test opterećenja i ultrazvuk srca, a vrlo često potrebna je dodana obradu kao stres scintigrafija miokarda ili koronarografija ${ }^{28,29}$.

Posebnu pažnju treba obratiti na obradu i probir na maligne bolesti. U muškaraca je to posebno obrada gastrointestinalnog trakta koja obavezno uključuje ezofakogastroskopiju i kolonoskopiju. U žena treba provoditi redovite mamografske i ginekološke preglede u cilju detekcije malignih bolesti.

\section{SPECIFIČNOSTI STARIJE POPULACIJE}

Starenjem se događaju određene anatomske i funkcionalne promjene u bubrezima, kao i promjene $u$ imunitetu te farmakokinetici lijekova.

\section{Starenje i bubrezi}

Tokom života dolazi do funkcionalnih i anatomskih promjena u bubrezima. Izloženost različitim bolestima tijekom života, kronična upala, faktori okoline uz genetske čimbenike imaju dodatni utjecaj na te promjene.

Bubrežna masa tijekom života se smanjuje, vrlo često se javljaju kalcifikacije i ciste. Broj glomerula se smanjuje, javlja se glomeruloskleroza, hipertrofija, promjene na podocitima i povećanje mezangija. Tubuli atrofiraju, smanjuje se njihova dužina, a također se javlja i intersticijska fibroza. Zbog tih promjena u tubulima je balans natrija i tekućina narušen, te je također povećana retencija kalija. U krvnim žilama javlja se ateroskleroza, intraluminalna hipertrofija i povećani tortuozitet krvnih žila, a te promjene utječu na perfuziju glomerula. Od endokrinoloških promjena javlja se povećana reninska aktivnost plazme, aktivnost aldosterona se smanjuje, koncentracija eritropoetina raste, ali se smanjuje odgovor na eritopoetin. Smanjena je i aktivacija vitamina D. Sve te promjene imaju posljedično smanjenje glomerularne filtracije u starijih osoba. Prema različitim studijama ona se nakon 40. godine života smanjuje za 0,4-2,4 ml/min godišnje. Zbog toga stariji imaju češće hipertenziju, sklonost retenciji tekućina i češćoj hiperkalijemiji ${ }^{30,31}$.

\section{Promjene u imunitetu starijih pacijenata}

Starenjem se događaju promjene u imunološkom sustavu. Osim starenja, na promjene utječu i prateće bolesti. Imunološki sustav sastoji se od urođenog i stečenog imuniteta. Promjene koje se javljaju starenjem utječu na oba imuniteta, ali više utjecaja imaju na stečeni imunitet. Sa starenjem se javlja involucija timusa. Posljedica toga je smanjeno stvaranja novih naivnih stanica. Također je i aktivnost imunoloških molekula smanjena ${ }^{32,33}$. 


\section{Farmakokinetika i farmakodinamika lijekova u starijih pacijenata}

Starija životna dob pacijenata je rizik za povećanje učestalosti neželjenih pojava lijekova, kao što su nefrotoksičnost, infekcije te maligne bolesti. Zbog toga stariji pacijenti zahtijevaju vrlo često smanjenje doze lijekova, uključujući i imunosupresivne lijekove ${ }^{34,35}$.

Sa starenjem se mijenja sastav tijela, povećava se udio masti na račun smanjenja vode u tijelu, što dovodi do povećanja koncentracije lipofilnih lijekova. Također, tijekom starenja dolazi do smanjenja mase jetre i smanjenja protoka krvi kroz jetru, što dodatno utječe na farmakokinetiku lijekova. Klirens bubrega se smanjuje, što može dodatno dovesti do povećanja koncentracije lijekova koji se izlučuju bubrezima.

\section{IMUNOSUPRESIVNA TERAPIJA U STARIJIH} PRIMATELJA BUBREŽNOG TRANSPLANTATA

Imunosupresivni protokoli u starijih primatelja uglavnom su slični kao kod mlađih. Najčešće se uz indukcijsku terapiju primjenjuje trojna imunosupresivna terapija koja se sastoji od kalcineurinskog inhibitora, mikofenolata i kortikosteroida. Zbog češćih pratećih bolesti i razvoja komplikacija, kao što su kardiovaskularne bolesti, malignitet i infekcije, pokušava se maksimalno individualizirati terapija u starijih pacijenata ${ }^{36,37}$. Navedene promjene koje se javljaju sa starenjem te u imunitetu i farmakokinetici također će dodatno utjecati na izbor imunosupresiva kao i na njihove doze $^{34,35}$.

\section{Indukcijska terapija}

Antitimocitni globulin (ATG) je poliklonalno antitijelo koji se koristi cijeli niz desetljeća u indukcijskoj terapiji u transplantaciji bubrega. Neželjene pojave uključuju ozbiljne reakcije preosjetljivosti kao što je anafilaksija i sindrom oslobađanja citokina, limfopenija, granulocitopenija i trombocitopenija. Također povećava rizik od oportunističkih infekcija, koje su povezane s većom dozom timocitnih globulina. Njihova upotreba u starijih pacijenata bila bi indicirana $u$ onih $s$ povećanim imunološkim rizikom, kao i u mlađih primatelja.

Blokator IL2, basiliximab široko je rasprostranjen u imunosupresivnim protokolima u indukcijskoj terapiji. Ima znatno manje neželjenih pojava, kao i manji rizik od infekcija. Prema provedenim ispitivanjima smatra se da u odnosu na ATG ima veću učestalost akutnog odbacivanja. Njegov izbor u indukcijskoj terapiji bio bi u primatelja manjeg imunološkog rizika, uključujući i starije pacijente, kao i kod bubrega darivatelja niskog imunološkog rizika $^{38,39}$.

\section{Kortikosteroidi}

Poznate se brojne komplikacije nakon transplantacije koje su povezane s terapijom kortikosteroidima kao: infekcije, otežano zacjeljivanje rana, osteoporoza, prijelomi, dijabetes, kardiovaskularni događaji, problemi s očima, usporavanje rasta u djece i pretilost ${ }^{37}$. U odnosu na mlađe primaoce, u starijih su one učestalije i teže. Minimiziranje ili izbjegavanje steroida nakon transplantacije bubrega može se preporučiti u starijih pacijenata s niskim imunološkim rizikom. Poznato je da je kasno izostavljanje kortikosteroida iz imunosupresivnih protokola (nakon tri mjeseca) povezano $s$ češćim krizama odbacivanja ${ }^{40}$. Rad Alsheikha i suradnika pokazao je da u starijih transplantiranih pacijenata (60 godina), u odnosu na mlađe $u$ kojih je primijenjen protokol ranog odvajanja kortikosteroida, nije bilo značajnije incidencije BK i CMV infekcije, kao ni učestalosti malignih bolesti i akutnog odbacivanja ${ }^{41}$.

\section{Kalcineurinski inhibitori}

Kalcineurinski inhibitori (CNI) su potentni imunosupresivi i njihovo uvođenje u imunosupresivne protokole je značajno poboljšalo preživljavanje bubrežnog transplantata. Upotreba takrolimusa ili ciklosporina uglavnom ovisi o protokolima $\mathrm{i}$ iskustvu pojedinih transplantacijskih centara, kako u mlađih tako i u starijih primatelja. Prema nekim studijama upotreba ciklospoina ima veći rizik od akutnog odbacivanja. Takrolimus je povezan s većim rizikom od nastanka poslijetransplantacijskog dijabetesa kao i BK virusne nefropatije. Rizik se povećava s dobi pacijenata. Promjene koje se događaju u bubrezima tijekom starenja su jedan od uzroka zašto je kalcineurinska toksičnost češća u starijih primatelja. Manje doze takrolimusa u starijih primatelja bubrežnog transplantata povezane su s boljim preživljavanjem 
kako transplantata tako i pacijenata. Također, učestalost malignih bolesti je otprilike duplo češća u pacijenata s imunosupresivnom terapijom u odnosu na opću populaciju, a u starijih primatelja učestalost malignih bolesti je još češća, čak od 8 do 11 puta. Zbog svega toga minimalizacija CNI-ja je poželjna u starijih pacijenata ${ }^{42,43}$.

\section{Antimetaboliti}

Azatioprin kao jedan od prvih imunosupresivnih lijekova u transplantaciji bubrega danas je gotovo u potpunosti zamijenjen mikofenolatom (MMF), koji se pokazao kao potentniji u suzbijanju imunološkog odgovora, kako u mlađih tako i u starijih primatelja bubrežnog transplantata. MMF se najčešće upotrebljava u kombinaciji s inhibitorom kalcineurina. Uglavnom se dobro podnosi. Može imati toksični efekt na koštanu srž (leukopenija), gastrointestinalne probleme i povećanu incidenciju infekcija ${ }^{36,37}$. Ponekad se u starijih primatelja zbog gastrointestinalnih problema mikofenolat može zamijeniti azatioprinom.

\section{mTOR inhibitori}

Upotreba mTOR inhibitora započela je krajem devedesetih godina prošlog stoljeća, najprije sirolimus, potom everolimus. Trebali su biti alternativa kalcineurinskim inhibitorima. Oni imaju antiviralna i antitumorska svojstva te zbog toga mogu imati povoljan učinak na smanjenje razvoja virusnih i malignih bolesti. Njihova uporaba povezana je sa specifičnim i ozbiljnim štetnim događajima kao: povećan rizik od odgođene funkcije bubrežnog transplantata, komplikacije u zacjeljivanju rana, veća učestalost limfocela, proteinurija i pojava hiperlipoproteinemije. Te neželjene pojave odgovorne su za prekid liječenja s mTOR inhibitorima. Također, dokazano je da je kasna konverzija povezana s više neželjenih pojava.

Iskustva s mTOR inhibitorima u starijih pacijenata ograničena su. Zbog svojih karakteristika, prvenstveno zato što nemaju nefrotoksični efekt, mogli bi imati više prednosti u imusupresivnom protokolu u starijih primatelja, pogotovo u starijih bubrega s postojećim vaskularnim lezijama ${ }^{37}$. Primjenu mTOR inhibitora treba razmotriti u imunosupesivnom protokolu u pacijenata s karcinomom prije transplantacije ili onima koji su razvili karcinom nakon transplantacije.

\section{SURADLJIVOST I IMUNOSPRESIJA}

\section{U STARIJIH PACIJENATA}

Stariji pacijenti vrlo često uzimaju velik broj lijekova. Transplantacijom se broj lijekova značajno povećava. Prema nekim radovima prosječan broj tableta koje uzimaju stariji transplantirani pacijenti je 11 tableta (od toga 6 imunosupresivni lijekovi i 5 tableta lijekova koji nisu imunosupresivi). Općenito u starijih pacijenata suradljivost $u$ uzimanju terapije opada nakon hospitalizacije.

Zbog češćih komorbiditeta i razvoja komplikacija kao što su kardiovaskularne bolesti, maligniteti, infekcije, pokušava se maksimalno individualizirati terapija u starijih pacijenata. Promjene koje se javljaju sa starenjem u imunološkom sustavu i farmakokinetici također će dodatno utjecati na izbor imunosupresiva, kao i na njihove doze.

Nakon uvođenja terapije, poslije tri mjeseca u 69 \% pacijenata zabilježena je nesuradljivost. Također, suradljivost opada i s većim brojem dnevnih doza. U odnosu na druge pacijente, suradljivost $u$ pacijenata s transplantiranim organima je povećana. Nesuradljivost u starijih pacijenata sigurno je povezana sa zaboravljivošću, depresijom i socioekonomskim okolnostima ${ }^{44-46}$.

\section{KIRURŠKE KOMPLIKACIJE U STARIJIH} PACIJENATA

Kirurške komplikacije neosporno utječu na brzinu oporavka nakon postupka transplantacije, te značajno utječu na trajanje hospitalizacije nakon zahvata. U starijih pacijenata zbog promjena na vaskularnim strukturama, kao što su aterosklerotske promjene i kalcifikacije krvnih žila, za očekivati je pojavu češćih vaskularnih komplikacija u odnosu na mlađe primatelje. Rad Bentasa i suradnika, naprotiv, nije pokazao veći postotak vaskularnih komplikacija u starijih primatelja, već je u odnosu na mlađe pacijente imao statistički značajno veću učestalost limfocela ${ }^{47}$. Sigurno da na ishode kirurških komplikacije, posebno na vaskularne komplikacije, ima utjecaj iskustvo kirurga ${ }^{48}$. Također se mora imati na umu da je sigurno priprema starijih primatelja, pogotovo u cilju procje- 
ne vaskularnog statusa, detaljnija. Općenito, do sada je objavljen mali broj radova koji govori o kirurškim komplikacijama u ovoj skupini pacijenata.

\section{ISKUSTVA U KBC-U RIJEKA S \\ TRANSPLANTACIJOM BUBREGA U STARIJOJ ŽIVOTNOJ DOBI}

Prva transplantacija bubrega u primatelja starijeg od 60 godina u KBC-u Rijeka učinjena je 1981. godine. U periodu od 1972. godine do 31. 12. 1999. učinjeno je 35 transplantacija u primatelja starijih od 60 godina, što je činilo $10 \%$ od ukupnog broja transplantacija bubrega od umrle osobe. Njihovo jednogodišnje preživljavanje iznosilo je $85 \%$, a najčešći uzrok smrti su bile kardiovaskularne bolesti ${ }^{49}$.

U periodu od 1990. do 2013. godine primatelji stariji od 65 godina činili su $14,5 \%$. Nije bilo razli-

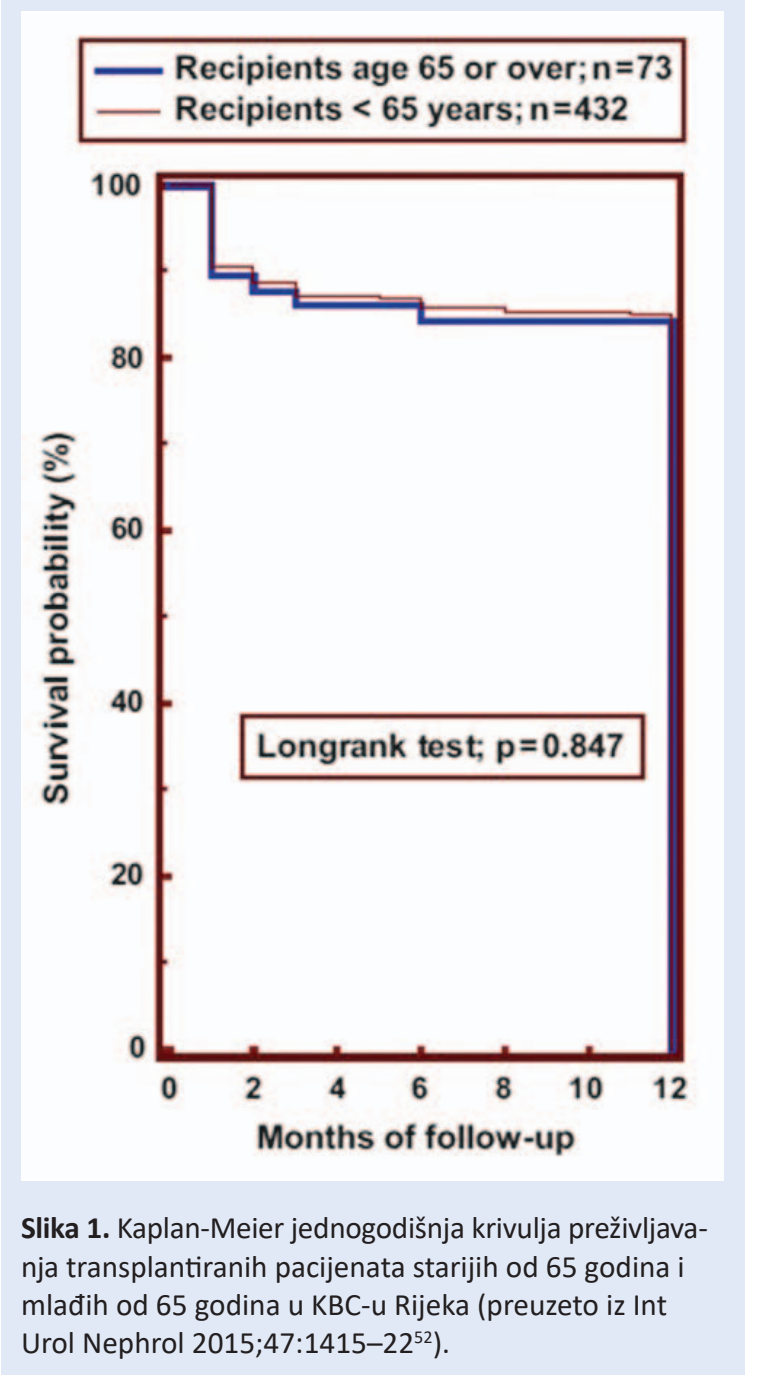

ke u njihovom jednogodišnjem preživljavanju u usporedbi s mlađim primateljima, kao ni u funkciji bubrežnog transplantata (slika 1). Jedino su lošiju funkciju bubrežnog transplantata imali stariji primatelji, koji su dobili transplantat od starijih darivatelja. Također, nije bilo razlike u odgođenoj funkciji bubrežnog transplantata, a u odnosu na mlađe imali su manje kriza akutnog odbacivanja ${ }^{50}$. Veći broj kirurških komplikacija, prema našem iskustvu, također je zabilježen u skupini starijih primatelja ${ }^{51}$.

Tendencija porasta broja primatelja starijih od 65 godina nastavlja se. Posljednjih godina oni danas čine oko trećinu novih transplantiranih pacijenata u KBC-u Rijeka. Najstariji primatelj bubrežnog transplantata do sada u KBC-u Rijeka imao je 80 godina.

\section{ZAKLJUČAK}

Transplantacija bubrega u starijih primatelja sve je učestalija metoda nadomještanja bubrežne funkcije. Prema podacima iz različitih registara ima bolje preživljavanje u odnosu na pacijente iste dobi koji su na listi čekanja. Transplantacija starijih primatelja od starijih darivatelja ima povećan rizik za odgođenu funkciju transplantata $\mathrm{i}$ razvoj infekcije. U prijetransplantacijskoj obradi, zbog većeg broja pratećih bolesti, posebnu pažnju treba obratiti na kardiovaskularne i maligne bolesti. Specifičnosti koje se javljaju sa starenjem utječu na imunitet primatelja te farmakodinamiku i farmakokinetiku lijekova, što treba imati na umu prilikom sastavljanja imunosupresivnog protokola, kao i mogućim interreakcijama.

Izjava o sukobu interesa: Autori izjavljuju da ne postoji sukob interesa.

\section{LITERATURA}

1. World Health Organisation. Good health adds life to years: global brief for World Health Day 2012;1-28.

2. Žene i muškarci u Hrvatskoj 2011. Državni zavod za statistiku Republike Hrvatske, Zagreb Ur:Ljiljana Ostroški.

3. Jager KJ, van Dijk PC, Dekker FW, Stengel B, Simpson K, Briggs JD et al. The epidemic of aging in renal replacement therapy: an update on elderly patients and their outcomes. Clin Nephrol 2003;60:352-60.

4. Hrvatsko društvo za nefrologiju, dijalizu i transplantaciju [Internet]. Hrvatski registar nadomještanja bubrežne funkcije. Izvještaj za 2014 godinu. [Cited 15 November 2019]. Available from: https://www.hdndt.org/registar/ hrn14.html. 
5. Orlić L, Sladoje-Martinović B, Maleta I, Živčić-Ćosić S, Vuksanović-Mikuličić $S$, Rački $S$. Nadomještanje bubrežne funkcije kroničnom hemodijalizom u KBC Rijeka. Medicina Fluminensis 2010;46:533-9.

6. Bunnapradist S, Danovich M. Kidney transplants for the elderly: Hope or hope?.Clin J Am Nephrol 2010;5:191011.

7. US Renal Data System 2019 Annual Data Report: Epidemiology of Kidney Disease in the United States. Am J Kidney Dis 2019;75:1-64.

8. Sørensen SS. Rates of renal transplantations in the elderly - data from Europe and the US. Transplant Rev (Orlando) 2015;29:193-6.

9. Huang E, Poommipanit N, Sampaio MS, Kuo HT, Reddy P, Gritsch HA et al. Intermediate-term outcomes associated with kidney transplantation in recipients 80 years and older: an analysis of the OPTN/UNOS database. Transplantation 2010;15:974-9.

10. Heldal K, Leivestad T, Hartmann A, Svendsen MV, Lien $\mathrm{BH}$, Midtvedt K. Kidney transplantation in the elderlythe Norwegian experience. Nephrol Dial Transplant 2008;23:1026-31.

11. Fabrizii V, Winkelmayer WC, Klauser R, Kletzmayr J, Saemann MD, Steininger $R$ et al. Patient and graft survival in older kidney transplant recipients: does age matter? J Am Soc Nephrol 2004;15:1052-60.

12. Rao P, Merion R, Ashby V, Port F, Wolfe R, Kayler L. Renal transplantation in elderly patients older than 70 years of age: results from the scientific registry of transplant recipients. Transplantation 2007;83:1069-74.

13. Doyle SE, Matas AJ, Gillingham K, Rosenberg ME. Predicting clinical outcome in the elderly renal transplant recipient. Kidney Int 2000;57:2144-50.

14. Hellemans R, Stel VS, Jager KJ, Bosmans JL, Abramowicz D. Do elderly recipients really benefit from kidney transplantation? Transplant Rev (Orlando) 2015;29:197-201.

15. Fujisawa M, Ichikawa $Y$, Yoshiya K, Isotani S, Higuchi A, Nagano $S$ et al. Assessment of health related quality of life in renal transplant and hemodialysis patients using the SF-36 health survey. Urology. 2000;56:201-16.

16. Jassal SV, Krahn MD, Naglie G, Zaltzman JS, Roscoe JM, Cole EH et al. Kidney transplantation in the elderly: a decision analysis. J Am Soc Nephrol 2003;14:187-96.

17. Gilla J, Schaeffnerd S, Chadbane S. Quantification of the early risk of death in elderly kidney transplant recipients. Am J Transplant. 2013;13:427-32.

18. Dempster NJ, Ceresa CD, Aitken E, Kingsmore D. Outcomes following renal transplantation in older people: a retrospective cohort study. BMC Geriatr 2013;13:79.

19. Yoo KD, An JN, Kim CT, Cho JH, Kim CD, Park SK et al. Clinical outcomes in Asian elderly kidney transplant recipients: a multicenter cohort study. Transplant Proc 2015;47:600-7.

20. Nanmoku K, Matsuda Y, Yamamoto T, Tsujita M, Hiramitsu T, Goto $\mathrm{N}$ et al. Clinical characteristics and outcomes of renal transplantation in elderly recipients.Transplant Proc 2012;44:281-3.

21. Impedovo SV, Ditonno P, Ricapito V, Bettocchi C, Gesualdo $L$, Grandiliano $G$ et al. Advanced age is not an exclusion criterion for kidney transplantation. Transplant Proc 2013;45:2650-3.

22. Orlandi PF, Cristelli MP, Aldworth CA, Freitas TV, Felipe $\mathrm{CR}$, Silva Junior $\mathrm{HT}$ et al. Long-term outcomes of elderly kidney transplant recipients. J Bras Nefrol 2015;37:21220.

23. Frideman A. Caution renal transplantation for the elderly is realistic. Nephron Clin Pract 2011;119:14-8.

24. Frei U, Noeldeke J, Machold-Fabrizii $\mathrm{V}$, Arbogast $\mathrm{H}$, Margreiter $R$, Fricke $L$ et al. Prospective age-matching in elderly kidney transplant recipients - a 5-year analysis of the Eurotransplant Senior Program. Am J Transplant 2008;8:50-7.

25. Annual report 2018. Eurotransplant Internatonal Foundation. 2018:1-108.

26. Gill J, Bunnapradist S, Danovitch GM, Gjertson D, Gill JS, Cecka M. Outcomes of kidney transplantation from older living donors to older recipients. Am J Kidney Dis 2008;52:541-52.

27. Morales E, Gutiérrez E, Hernández A, Rojas-Rivera J, Gonzalez E, Hernández E et al. Preemptive kidney transplantation in elderly recipients with kidneys discarded of very old donors: A good alternative. Nefrologia 2015;35: 246-55.

28. Ponticelli C, Podestà MA, Graziani G. Renal transplantation in elderly patients. How to select the candidates to the waiting list? Tranplant Rev 2014,28:188-92.

29. Sladoje-Martinović B, Orlić L, Živčić-Ćosić S, VuksanovićMikuličić S. Priprema pacijenata za transplantaciju bubrega. Medicina Fluminensis 2010;46:508-12.

30. Lerma EV . Anatomic and physiologic changes of the aging kidney. Clin Geriatr Med 2009;25:325-9.

31. Karam Z, Tuazon J. Anatomic and Physiologic Changes of the Aging Kidney. Clin Geriatr Med 2013;29:555-64.

32. Kinger M, Banasik M. Immunological characteristic of elderly alograft recipient. Transplant Rev 2015;29:2019-223.

33. McKay D, Jameson J. Kidney transplantation and the ageing immune system. Nat Rev Nephrol. 2012;8:700-8.

34. Shi YY, Hesselink DA, van Gelder T. Pharmacokinetics and pharmacodynamics of immunosuppressive drugs in elderly kidney transplant recipients. Transplant Rev 2015; 29:229-31.

35. Kuypers DR. Immunotherapy in elderly transplant recipients: a guide to clinically significant drug interactions. Drugs Aging 2009;26:715-37.

36. Iwamoto $\mathrm{H}$, Nakamura $\mathrm{Y}$, Konno O, Tomita K, Ueno $\mathrm{T}$, Yokoyama $Y$ et al. Immunosuppressive therapy for elederly kidney transplant recipients. Transplant Proc 2016;48:799-801.

37. Krenzien F, Elkhal A, Quante M, Rodriguez Cetina Biefer H, Hirofumi U, Gabardi SA. Rationale for age-adapted immunosuppression in organ transplantation. Transplantation. 2015;99:2258-68.

38. Brennan DC, Daller JA, Lake KD, Cibrik D, Del Castillo D. Rabbit antithymocyte globulin versus basiliximab in renal transplantation. N Engl J Med 2006;355:1967-77.

39. Patel SJ, Knight RJ, Suki WN, Abdellatif A, Duhart BT, Krauss $A G$ et al. Rabbit antithymocyte induction and dosing in deceased donor renal transplant recipients over 60 years of age. Clin Transplant 2011;25:250-6.

40. Matas AJ. Steroid elimination - who, when, how? Transplant Proc 2008;40: S52-S6.

41. Alsheikh R, Gabardi S. Post-renal transplantation outcomes in elderly patients compared to younger patients in the setting of early steroid withdrawal. Prog Transplant 2018;28:322-9. 
42. Heldal K, Midtvedt K. Managing transplant rejection in the elderly: The benefits of less aggressive immunosuppressive regimens. Drugs Aging 2013;30:459-66.

43. Badowski M, Gurk-Turner C, Cangro C, Weir M, Philosophe $B$, Klassen $D$ et al. The impact of reduced immunosuppression on graft outcomes in elderly renal transplant recipients. Clin Transplant 2009:23:930-7.

44. Germani G, Lazzaro S, Gnoato F, Senzolo M, Borella V, Rupolo $G$ et al. Nonadherent behaviors after solid organ transplantation. Transplant Proc 2011;43:318-23.

45. Su GC, Greanya E, Partovi N, Yoshida EM, Shapiro RJ, Levy RD. Assessing medication adherence in solid-organ transplant recipients. Exp Clin Transplant 2013;6:475-81.

46. Butler JA, Roderick P, Mullee M, Mason JC, Peveler RC. Frequency and impact of nonadherence to immunosuppressants after renal transplantation: a systematic review. Transplantation 2004;77:769-76.

47. Bentas W, Jones J, Karaoguz A, Tilp U, Probst M, Scheuermann $\mathrm{E}$ et al. Renal transplantation in the elderly: surgi- cal complications and outcome with special emphasis on the Eurotransplant Senior Programme. Nephrol Dial Transplant 2008;23:2043-51.

48. Kulu Y, Fathi P, Golriz M, Khajeh E, Sabagh M, Ghamarnejad $O$ et al. Impact of surgeon's experience on vascular and haemorrhagic complications after kidney transplantation. Eur J Vasc Endovasc Surg 2019;57:139-49.

49. Orlić L, Martinović Sladoje B, Matić Glažar $Đ$, Orlić $P$, Maleta I, Vukas D. Kadaverična transplantacija bubrega u pacijenata starijih od 60 godina. Med Arh 2001;55:20910.

50. Mikolašević I, Rački S, Španjol J, Župan Ž, Jakopčić I, Devčić B, Orlić L. Outcomes following renal transplantation in older renal transplant recipients: a single-center experience and "Croatian senior program". Int Urol Nephrol 2015;47:1415-22.

51. Markić $D$, Valenčić $M$, Oguić $R$, Rački S, Fučkar Ž. Kidney transplantation in elderly patients. Coll Antropol 2011; 35:175-8. 